Rahlff et al.

Dispersal of Antarctic phage

\section{Ralstonia}

\title{
Host-associated phages disperse across the extraterrestrial analogue
}

\section{Antarctica}

\author{
Running title: Dispersal of Antarctic phage
}

\author{
Janina Rahlff ${ }^{a, \#, ~ T i l l ~ L . V . ~ B o r n e m a n n ~}{ }^{a}$, Anna Lopatinab,
} Konstantin Severinov ${ }^{\mathrm{b}}$, Alexander J. Probst ${ }^{\mathrm{a}, \mathrm{c}}$

${ }^{\mathrm{a}}$ Group for Aquatic Microbial Ecology, University of Duisburg-Essen, Department of Chemistry, Environmental Microbiology and Biotechnology (EMB), Universitätsstraße 5, ${ }^{\mathrm{b}}$ Institutes of Molecular Genetics and Gene Biology of the Russian Academy of Sciences,

\#Corresponding author: Janina Rahlff, Janina.rahlff@,uol.de

Present address: Centre for Ecology and Evolution in Microbial Model Systems (EEMiS), Department of Biology and Environmental Science, Linnaeus University, SE-39182, Kalmar, 
bioRxiv preprint doi: https://doi.org/10.1101/2021.11.09.467789; this version posted February $19,2022$. The copyright holder for this preprint (which was not certified by peer review) is the author/funder, who has granted bioRxiv a license to display the preprint in perpetuity. It is made available under aCC-BY-NC-ND 4.0 International license.

Rahlff et al.

Dispersal of Antarctic phage

\section{Abstract}

Extreme Antarctic conditions provide one of the closest analogues of extraterrestrial

environments. Since air and snow samples, especially from polar regions, yield DNA amounts

in the lower picogram range, binning of prokaryotic genomes is challenging and renders studying the dispersal of biological entities across these environments difficult. Here, we hypothesized that dispersal of host-associated bacteriophages (adsorbed, replicating or prophages) across the Antarctic continent can be tracked via their genetic signatures aiding our understanding of virus and host dispersal across long distances. Phage genome fragments (PGFs) reconstructed from surface snow metagenomes of three Antarctic stations were assigned to four host genomes, mainly Betaproteobacteria including Ralstonia spp. We reconstructed the complete genome of a temperate phage with near-complete alignment to a prophage in the reference genome of Ralstonia pickettii 12D. PGFs from different stations were related to each other at the genus level and matched similar hosts. Metagenomic read mapping and nucleotide polymorphism analysis revealed a wide dispersal of highly identical PGFs, 13 of which were detected in seawater from the Western Antarctic Peninsula in distance of $5538 \mathrm{~km}$ to the snow sampling stations. Our results suggest that host-associated phages, especially of Ralstonia sp., disperse over long distances despite harsh conditions of the Antarctic continent. Given that 14 phages associated with two $R$. pickettii draft genomes isolated from space equipment were identified, we conclude that Ralstonia phages are ideal mobile genetic elements to track dispersal and contamination in ecosystems relevant for Astrobiology. 
bioRxiv preprint doi: https://doi.org/10.1101/2021.11.09.467789; this version posted February 19, 2022. The copyright holder for this preprint (which was not certified by peer review) is the author/funder, who has granted bioRxiv a license to display the preprint in perpetuity. It is made available under aCC-BY-NC-ND 4.0 International license.

Rahlff et al.

Dispersal of Antarctic phage

\section{Importance}

Host-associated phages of the bacterium Ralstonia identified in snow samples can be used to track microbial dispersal over thousands of kilometers across the Antarctic continent, which functions as an extraterrestrial analogue because of its harsh environmental conditions. Due to presence of these bacteria carrying genome-integrated prophages on space-related equipment, and the here demonstrated potential for dispersal of host-associated phages, our work has implications for Planetary Protection, a discipline in Astrobiology interested in preventing contamination of celestial bodies with alien biomolecules or forms of life.

\section{Introduction}

Due to harsh environmental conditions and isolation by the surrounding Southern Ocean's

Circumpolar Current, Antarctica is considered an analogue for multipurpose space exploration $(1,2)$. For example, its McMurdo Dry Valleys are regarded as a close terrestrial analogue to Mars (3). Astrobiology model organisms found on Antarctica are highly adapted to stressful conditions and comprise prokaryotes such as spore-forming Bacilli $(4,5)$, but also microfungi $(3,6)$. Understanding endurance and dispersal of microorganisms under conditions that mimic those on extraterrestrial planets, i.e., high UV radiation, low temperature, and low nutrient availability, has important implications for Planetary Protection. For instance, the dispersal of microbes that hitchhike to a celestial body is currently not considered in Planetary Protection, a discipline in Astrobiology set out with the aim of preventing contamination of celestial bodies with foreign biomolecules or forms of life. 
bioRxiv preprint doi: https://doi.org/10.1101/2021.11.09.467789; this version posted February 19, 2022. The copyright holder for this preprint (which was not certified by peer review) is the author/funder, who has granted bioRxiv a license to display the preprint in perpetuity. It is made available under aCC-BY-NC-ND 4.0 International license.

Rahlff et al.

Dispersal of Antarctic phage

Among the potential candidates hitchhiking spacecraft are Betaproteobacteria of the genus Ralstonia (order Burkholderiales). These bacteria are able to thrive under oligotrophic conditions (7) and were reported to be ubiquitously present on space-related equipment including water systems of the International Space Station (ISS) $(8,9)$, and the Mir space station $(10,11)$. Likewise, they belonged to the microbial inventory of Mars Odyssey and Mars Phoenix lander facilities and can thus prevail under strict Planetary Protection regulations (12, 13). Ralstonia pickettii strains were found to thrive in simulated microgravity compared to normal gravity (11) and demonstrated high resistance against different metal ions and UV-C radiation $(8)$.

Ralstonia spp., (mainly R. pickettii), were previously found Antarctic soils (14), Antarctic snow (15-17), in snow over Tibetan Plateau Glaciers (18), and in the air of the Antarctic base Concordia (19). Interestingly, this genus has been regarded as an atmospheric traveler rather than being part of true snow microflora in Antarctica (15). Despite a report on bacterial activity at subzero temperatures in South pole snow (20), Ralstonia was not among active bacterial communities as inferred from cDNA-based 16S rRNA amplicon sequencing (15). This view was supported by a comprehensive Antarctic surface snow microbiome study that did not detect this bacterial genus (21), and by the fact that spatial variability of snow microbiomes in Antarctica is high (22). Although aerial dispersal is probably the major contributor to (micro)biological input to remote regions (23), the role of bioaerosol transport to microbial ecology of isolated systems such as the Antarctic continent is poorly understood (24). Applying high throughput sequencing approaches to study bacterial dispersal over the Antarctic continent remains a considerable challenge due to the low microbial biomass of atmosphere-derived samples regarding their DNA content (25), and resulting issues of recovering high quality assemblies from metagenomic reads (26). 
bioRxiv preprint doi: https://doi.org/10.1101/2021.11.09.467789; this version posted February 19, 2022. The copyright holder for this preprint (which was not certified by peer review) is the author/funder, who has granted bioRxiv a license to display the preprint in perpetuity. It is made available under aCC-BY-NC-ND 4.0 International license.

Rahlff et al.

Dispersal of Antarctic phage

In addition to the limited knowledge about how transport via aerosols and snow across Antarctica shapes microbial dispersal patterns, another open question relates to the distances that microbes can cover within the atmosphere of extreme environments. A study on the dispersal of airborne faecal coliforms showed a distribution over about just $175 \mathrm{~m}$ from a sewage outfall at Rothera Research Station (Antarctic Peninsula) and thus prolonged survival was considered unlikely (27). More stress-resistant microorganisms could, however, endure for much longer periods. Recently, L. A. Malard et al. (22) found high abundances of sporeforming Bacilli and suggested that long-term dispersal may seed continental Antarctic snow ecosystems. However, to date, the role of aerial dispersal in shaping patterns of microbial biogeography is supported by little empirical evidence (23).

Here, we follow the hypothesis that geographically widespread (28) Ralstonia spp. prophages and/or replicating and adsorbed bacteriophages of this genus (all types further referred to as "host-associated" phages) can be used to study host bacterium dispersal across the Antarctic continent. Reconstructing prokaryotic genomes from samples containing low amounts of DNA, including air or precipitation is challenging, as low input libraries $(\sim 1 \mathrm{pg})$ can result in problems of genome binning (26). However, (pro)phage genomes or their fragments are much smaller than prokaryotic genomes and thus easier to identify, track and compare. In this study, genomeresolved metagenomics was applied to demonstrate dispersal of host-associated phage genome fragments (PGFs) from surface snow across the Antarctic continent over hundreds to thousands of kilometers. We detected PGFs belonging to the orders Caudovirales and Tubulavirales in this extraterrestrial analogue and additionally show that similar genome-integrated phages are frequent colonizers of space equipment. Therefore, we suggest that host-associated PGFs represent a useful tool to study spatial dispersal of bacteria and their phages in extreme environmental settings and further envision implications for the dispersal of microbiological 
bioRxiv preprint doi: https://doi.org/10.1101/2021.11.09.467789; this version posted February 19, 2022. The copyright holder for this preprint (which was not certified by peer review) is the author/funder, who has granted bioRxiv a license to display the preprint in perpetuity. It is made available under aCC-BY-NC-ND 4.0 International license.

Rahlff et al.

Dispersal of Antarctic phage

121 contaminations on spacecraft and celestial bodies that previously escaped Planetary Protection 122 measures.

\section{Results}

\section{Reconstruction of low coverage MAGs from Antarctic snow metagenomic data}

The microbial community composition of surface snow samples collected close to three Russian collected at the Mirnii station, the second most dominant after Janthinobacterium at Druzhnaja,

130 and the third most dominant (after Flavobacteria and Hydrogenophaga) around Progress

131 station. We reconstructed four prokaryotic and one eukaryotic metagenome assembled genomes

132 (MAG) from the three low-biomass snow metagenomes (Figure 1A). Two MAGs related to

133 Ralstonia sp. and R. pickettii were recovered from Druzhnaja and Mirnii samples and had

$13486 \% / 10 \%$ and $55 \% / 0 \%$ completeness/contamination scores, respectively. MAGs of

135 Janthinobacterium lividum with $92 \% / 6 \%$ scores and of Flavobacterium micromati with

$13696 \% / 0 \%$ scores were recovered from Druzhnaja and Progress, respectively. We also identified

137 a MAG of a diatom (likely Thalassiosira sp.) in the Mirnii metagenome, which we used for

138 normalizing some of our viral analysis (see below) but was not further characterized in this

139 work. Read mapping revealed coverage scores of 5.9, 7.1, 6.7 and 14.6 for the MAGs of

140 Ralstonia sp., R. pickettii, J. lividum and F. micromati, respectively.

\section{Prevalent absence of CRISPR-Cas systems suggest low adaptive immunity}

142 We searched for clustered regularly interspaced short palindromic repeats (CRISPR) spacers in

143 the snow metagenome reads to link them to potential protospacers on PGFs. CRISPR arrays 
bioRxiv preprint doi: https://doi.org/10.1101/2021.11.09.467789; this version posted February 19, 2022. The copyright holder for this preprint (which was not certified by peer review) is the author/funder, who has granted bioRxiv a license to display the preprint in perpetuity. It is made available under aCC-BY-NC-ND 4.0 International license.

Rahlff et al.

Dispersal of Antarctic phage

144 and cas genes were absent from both Ralstonia and the J. lividum MAGs as determined by

145 CRISPRcasFinder (29). BLASTing of direct repeat (DR) sequences to NCBI's NR database

146 also did not indicate Ralstonia or Janthinobacterium to be the host of the CRISPR array. Solely

147 the genome of F. micromati contained two CRISPR arrays with four spacers each (both

148 evidence level 3 = highly likely candidates). CRISPR arrays were not detected on $R$. pickettii

149 draft genomes SSH4 and CW2 obtained from space equipment.

PGF-host analyses suggest shared hosts of Antarctic phages

A total of 26 predicted PGFs, eight of them being putative PGFs, was found in Antarctic snow metagenomic data (Table S1). VIBRANT (30) additionally detected 52 PGFs, resulting in a total of 78 PGFs (Figure 1A). PGFs with minimum $75 \%$ of the genome covered with reads had coverages ranging between 1.9 and 17.5. Most PGFs were partial sequences according to

Antarcphage49_Dr_7823_circ were estimated to be of full length (Table S1), although annotations of Antarcphage10_Mi_4716 in comparison to Ralstonia phage p12J revealed missing genes and let us question its completeness (Figure 2). Out of 78 PGFs, 77 were categorized as lytic by VirSorter (33) and 75 were found to be of viral or unclassified origin by the Druzhnaja, Mirnii and Progress, respectively. (34). We defined a dissimilarity threshold of $\mathrm{d} 2 *$ value $=0.436$, which corresponds to the lowest dissimilarity value (= highest similarity) for PGFs matching the MAG of Thalassiosira sp. from the snow environment (Figure 1A) by assuming that the eukaryotic MAG does not match any

167 of our extracted prokaryote infecting PGFs. In total, 50 of the 78 PGFs matched a host MAG 
bioRxiv preprint doi: https://doi.org/10.1101/2021.11.09.467789; this version posted February 19, 2022. The copyright holder for this preprint (which was not certified by peer review) is the author/funder, who has granted bioRxiv a license to display the preprint in perpetuity. It is made available under aCC-BY-NC-ND 4.0 International license.

Rahlff et al.

Dispersal of Antarctic phage

168 below the defined dissimilarity threshold, based on their shared k-mer patterns. Most PGFs (41)

169 matched both MAGs of Ralstonia sp. and R. pickettii (Figure 1A). In total, 38 and 14 PGFs

170 matched J. lividum and F. micromati MAGs, respectively. Five out of eight PGFs extracted

171 from the Progress station metagenomic snow sequences matched the F. micromati MAG

172 recovered from this station. Seven PGF matches were shared between all prokaryotic MAGs

173 (Figure S1). However, with 30 shared matches, the three MAGs belonging to the order

174 Burkholderiales shared the most overlap (Figure 1B, Figure S1).

175 Matching of CRISPR spacers derived from CRISPR loci of unknown hosts (reconstructed from

176 DR sequences) revealed that spacers from Mirnii matched 19, 14 and three PGFs from

177 Druzhnaja, Mirnii and Progress, respectively, and one Flavobacterium sp. spacer from Progress

178 matched a PGF from that station (Figure 1C, Table S2, $\geq 80 \%$ similarity). Out of these 37 spacer

179 matches, three matched protospacers of PGFs of unknown hosts, and 26 were assigned to a

180 Ralstonia host according to VirHostMatcher or other predictions (Table S1). Since p12D (see

181 below) was among the PGF spacer targets and is a certain Ralstonia phage, this could indicate

182 that an unknown host belonging to the order Burkholderiales uses adaptive immunity against

183 viruses. We compiled evidence of host prediction for the 78 PGFs in Table S1. 
A

\begin{tabular}{|c|c|c|c|c|c|c|}
\hline \multicolumn{7}{|c|}{ Stations } \\
\hline 1. & \multicolumn{2}{|l|}{$\stackrel{\text { Mirnii }}{L}$} & \multicolumn{3}{|c|}{ Druzhnaja } & \multirow{2}{*}{ Host genomes } \\
\hline \multirow{2}{*}{\multicolumn{7}{|c|}{$\# 1 \longrightarrow \# 8 \# 9$}} \\
\hline & & & & & & \\
\hline & 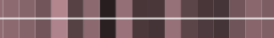 & C & 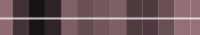 & & & \multirow{2}{*}{$\begin{array}{l}\text { Ralstonia sp. } \\
\text { Ralstonia pickettii } \\
\text { Thalassiosira sp. } \\
\text { Flavobacterium micro }\end{array}$} \\
\hline & & & & & & \\
\hline \multicolumn{7}{|c|}{ Individual phage genome fragments } \\
\hline \multirow{5}{*}{ 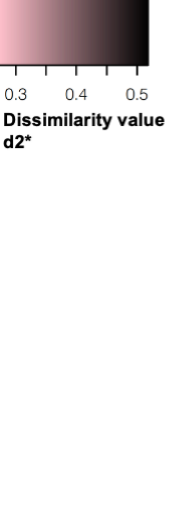 } & Station & Progress & Mirnii & Mirnii & Druzhnaja & Druzhnaja \\
\hline & $\begin{array}{l}\text { Phylogenetic } \\
\text { affiliation of host } \\
\text { genome (species) }\end{array}$ & $\begin{array}{l}\text { Flavo- } \\
\text { bacterium } \\
\text { micromati }\end{array}$ & $\begin{array}{l}\text { Thalassiosira } \\
\text { sp. }\end{array}$ & $\begin{array}{l}\text { Ralstonia } \\
\text { pickettii }\end{array}$ & Ralstonia sp. & \begin{tabular}{|l|} 
Janthino- \\
bacterium \\
lividum
\end{tabular} \\
\hline & (family) & $\begin{array}{l}\text { (Flavobacteria } \\
\text { ceae) }\end{array}$ & $\begin{array}{l}\text { (Thalassiosira } \\
\text { ceae) }\end{array}$ & $\begin{array}{l}\text { (Burkholderiac } \\
\text { eae) }\end{array}$ & $\begin{array}{l}\text { (Burkholderia } \\
\text { ceae) }\end{array}$ & $\begin{array}{l}\text { (Oxalobacter } \\
\text { aceae) }\end{array}$ \\
\hline & $\begin{array}{l}\text { Completeness (\%)/ } \\
\text { contamination (\%) }\end{array}$ & $96 / 0$ & $\mathrm{n} / \mathrm{a}$ & $55 / 0$ & $86 / 10$ & $92 / 6$ \\
\hline & Coverage & 14.6 & 32.1 & 7.1 & 5.9 & 6.7 \\
\hline & & & & & & \\
\hline
\end{tabular}

B

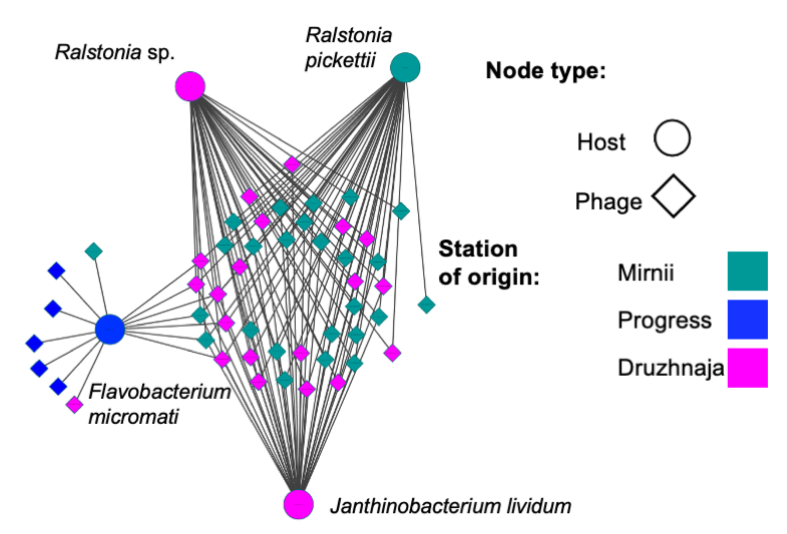

C

Node type:

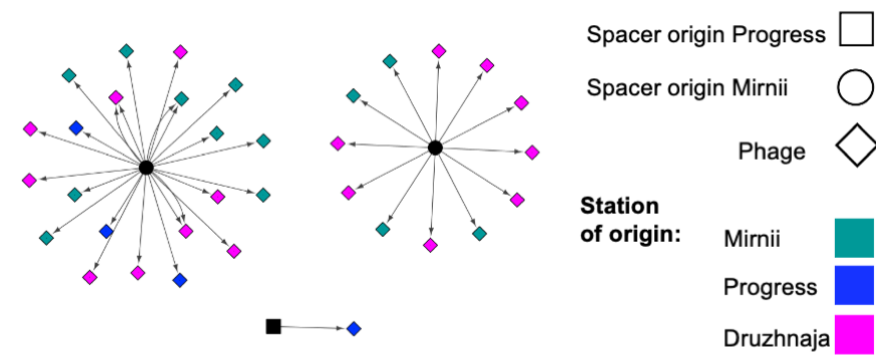

Figure 1: Host-phage pairings based on shared k-mer frequency patterns. A) Heatmap representing dissimilarity value d2* for matches between

187 five host MAGs and 78 PGFs derived from three Antarctic snow metagenomes from the stations Progress, Mirnii, and Druzhnaja. The PGF number 
Rahlff et al.

190 on k-mer frequency pattern reveals strong overlap between Ralstonia and Janthinobacterium lividum infecting PGFs. Here, only PGFs matching the

191 host MAG below the defined threshold (see text) are shown. C) CRISPR spacer matches to PGFs. Different spacers matching to the same PGFs are

192 shown by multiple arrows. The two hosts of CRISPR arrays for Mirnii-derived spacers remain unidentified according to their direct repeat sequence,

193 whereas the Progress spacer is derived from a Flavobacterium sp. (Table S2). 
Rahlff et al.

Dispersal of Antarctic phage

The temperate phage p12D forms a distinct, monophyletic clade excluding most known

\section{Ralstonia phages}

Among the 78 PGFs, we detected a circular (and thus complete) $7.8 \mathrm{~kb}$ PGF termed Antarcphage49_Dr_7823_circ(Figure 2A, Figure S2). Since the Antarcphage49_Dr_7823_circ

PGF from the Druzhnaja station was found in the chromosome of a $R$. pickettii 12D strain

Antarcphage49_Dr_7823_circ (from now on referred to as p12D) only matched the MAG of

Ralstonia sp. and $R$. pickettii based on shared k-mer frequency patterns. Functional protein annotations provided evidence that $\mathrm{p} 12 \mathrm{D}$ contained a gene for a resolvase domain containing protein/site-specific recombinase, likely used for integration into the host genome, as well as for the zonular occludens toxin (Zot, PF05707) (Figure 2A, Figure S2, Table S3). The non-

toxic component of Zot at the N-terminus represents a characteristic protein in filamentous phages that has been used for phage classification $(35,36)$. Reconstruction of a phylogenetic relationships of Zot proteins from this study and respective references (Figure 2B, Figure S3)

211 confirmed a close identity of p12D to Ralstonia phage 1 NP-2014 and 212 Antarcphage79_WAP_18.3, all belonging to the same monophyletic clade. Zot of 213 Antarcphage10_Mi_4716 was phylogenetically related to filamentous Ralstonia phage p12J.

214 The tree shows four distinctive clusters for the Zot protein, reflecting the overall synteny of the 215 gene order of the different Ralstonia phages very well.

216 Annotations against UniRef100 revealed that $68.8 \%$ of all annotated Antarctic PGF proteins 217 remain hypothetical. The annotations taxonomically assigned $34.4 \%$ of all Antarctic PGF 218 proteins to either Ralstonia or R. pickettii, and $11.6 \%$ to phages of Janthinobacterium or J. 
bioRxiv preprint doi: https://doi.org/10.1101/2021.11.09.467789; this version posted February 19, 2022. The copyright holder for this preprint (which was not certified by peer review) is the author/funder, who has granted bioRxiv a license to display the preprint in perpetuity. It is made available under aCC-BY-NC-ND 4.0 International license.

Rahlff et al.

Dispersal of Antarctic phage

lividum, potentially indicating lateral gene transfer between virus and host in their respective evolution $(37,38)$ or supporting that these PGF indeed represent prophages. Three of the Antarctic PGFs carried a site-specific integrase or resolvase domain, and $4.2 \%$ of genes were related to phage structural proteins, e.g., head, tail, or capsid proteins (Table S4, Table S5).

A
B

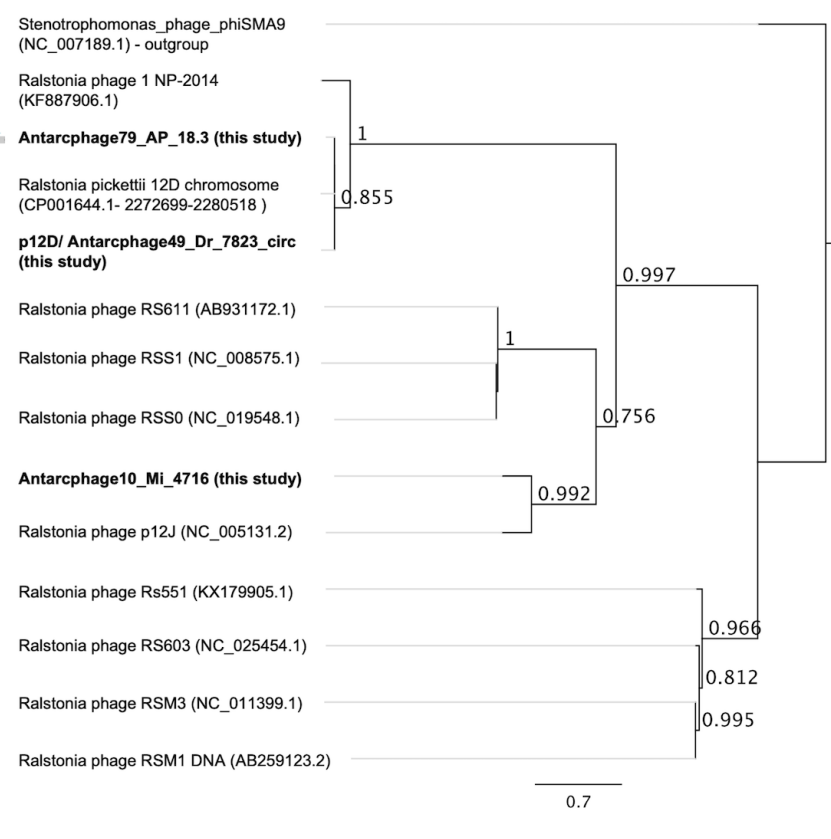

Figure 2: Phage genome comparisons, functional annotations and phylogenetic relationship based on zonular occludes toxin (Zot, Pfam-ID: PF05707). A) Synteny of known Ralstonia sp. phages from NCBI and Antarctic PGFs from this study with similar coding sequences (CDS) being in the same color if they occur on more than one phage genome. Functional annotations performed by DRAM-v (115) are given for all colored CDS where available. Vertical lines between sequences indicate regions of shared similarity shaded according to tBLASTx (orange gradient for matches in the same direction or blue gradient for inverted matches). Figure was created using Easyfig (119). B) The phylogenetic tree was built using FastTree 2.1.11 (122) in Geneious 11.1.5 (112) under default settings and shows four distinct clusters of Zot proteins based on their amino acid sequences (aligned with MUSCLE $(121))$. 
bioRxiv preprint doi: https://doi.org/10.1101/2021.11.09.467789; this version posted February 19, 2022. The copyright holder for this preprint (which was not certified by peer review) is the author/funder, who has granted bioRxiv a license to display the preprint in perpetuity. It is made available under aCC-BY-NC-ND 4.0 International license.

Rahlff et al.

Dispersal of Antarctic phage

\section{Cross-mapping and nucleotide variations reveal dispersal patterns of MAGs and PGFs}

\section{across Antarctica}

239 Mapping of $100 \%$ identical reads from the three snow samples and the Western Antarctic 240 Peninsula (WAP, Figure 3A) seawater sample to the prokaryotic MAGs revealed that both 241 Ralstonia MAGs were detected at all sites (89-100\% genome coverage). J. lividum was 242 considered absent from the Progress station (genome coverage of 62\%) and detected at other stations (minimum 95\% covered genome). F. micromati was only detected in Progress (100\%)

244 and Druzhnaja (96\%) but considered absent from Mirnii (58.7\%) and the WAP (1.8\%). Cross245 mapping on the 78 PGFs demonstrated that PGFs derived from the Progress station could not 246 be found in the other two snow metagenomes (Figure 3B\&C). By contrast, 16 different PGFs 247 from Druzhnaja were detected at Mirnii, and 27 Mirnii PGFs were found at Druzhnaja (Figure 248 3C). In addition, 4 and 9 PGFs from Mirnii and Druzhnaja were detected in the WAP dataset, 249 respectively (Figure $3 \mathrm{~B} \& \mathrm{C}$ ), all of them having minimum 97\% of their lengths covered with 250 reads from the snow metagenomes (Table S1). Of 43 PGFs that were found at both stations 251 (Mirnii and Druzhnaja) based on read mapping, 26 PGFs shared a viral cluster (VC), and 34 252 matched prokaryotic hosts based on k-mer frequencies between stations (Table S1). 253 Interestingly, nine of the 13 PGFs occurring in WAP and Mirnii/Druzhnaja samples contained 254 identical single nucleotide polymorphisms (SNPs, Figure 3D\&E, Table S6) or were missing common SNPs pointing towards a common phage population before dispersal led to separation.

257 Clustering of PGFs in VICTOR (39) and vConTACT2 (40) revealed that groups of two to four 258 PGFs could be assigned to twelve distinct viral genera-forming viral clusters (Figure 3E, Figure 259 S4 \& S5, Table S1). Members of the same cluster were often recovered from different stations, 260 for example, Druzhnaja and Mirnii (Figure 3B), which are located $923 \mathrm{~km}$ apart (Figure 3C). 261 The phylogenomic Genome-BLAST Distance Phylogeny (GBDP) tree yielded average support 
bioRxiv preprint doi: https://doi.org/10.1101/2021.11.09.467789; this version posted February 19, 2022. The copyright holder for this preprint (which was not certified by peer review) is the author/funder, who has granted bioRxiv a license to display the preprint in perpetuity. It is made available under aCC-BY-NC-ND 4.0 International license.

Rahlff et al.

Dispersal of Antarctic phage

of $47 \%$ and $80 \%$ in the nucleic acid and amino acid-based analysis, respectively. OPTSIL

at the amino acid level, respectively.

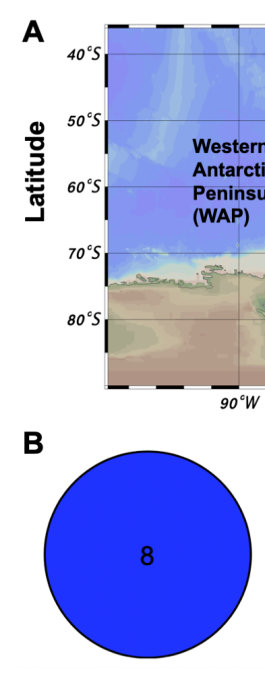

Site of Progress phage origin:

D

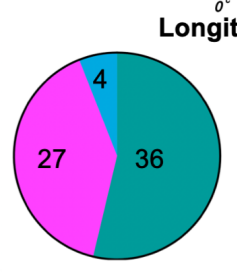

Mirnii
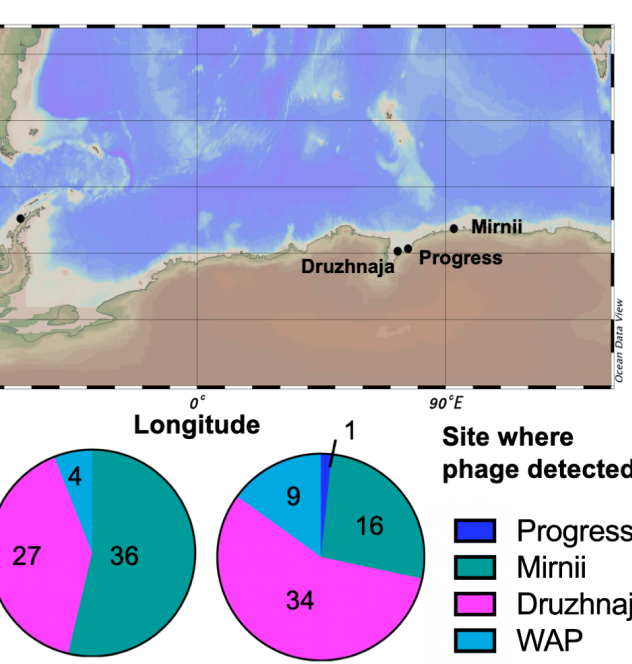

Druzhnaja

Site where phage detected:

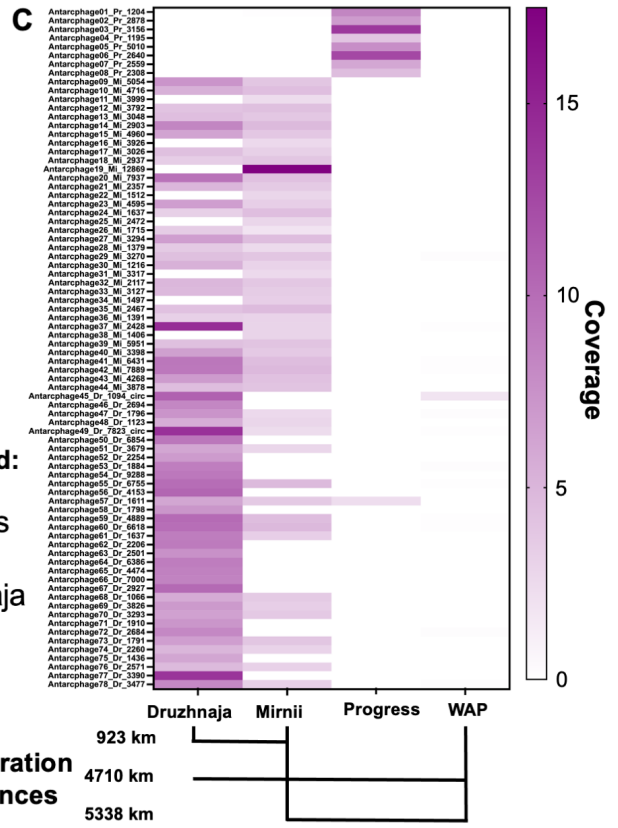

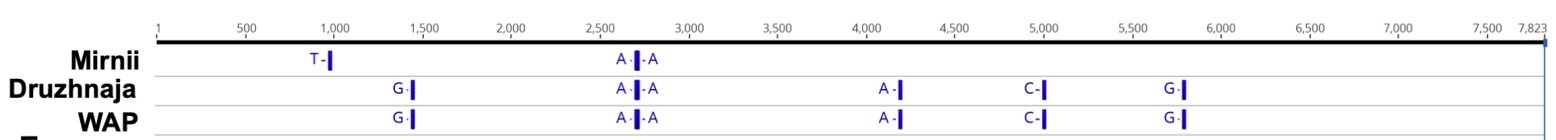

E

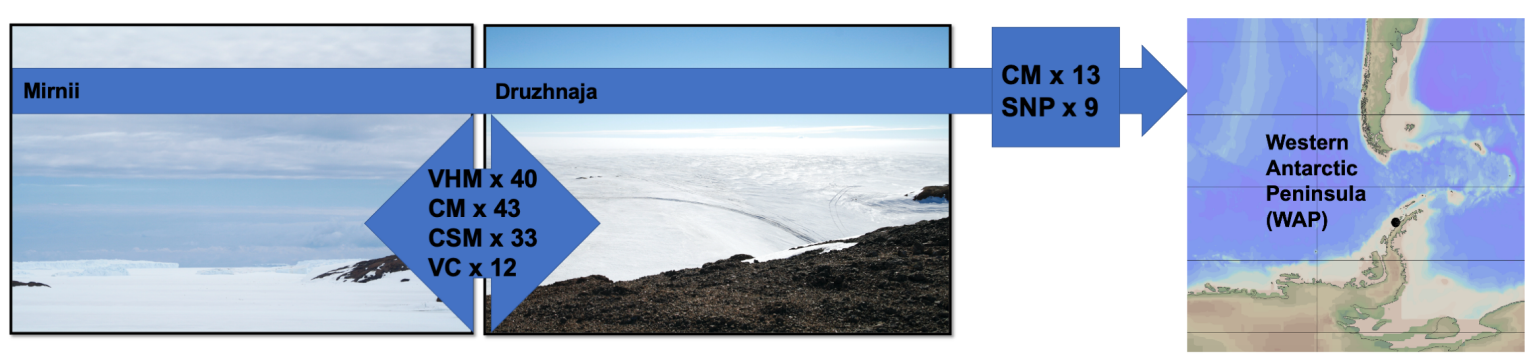

Figure 3: Evidence for dispersal of PGFs across the Antarctic continent. A) A map showing

267 the different snow sampling stations in the East and the sampling station for seawater at the

268 Western Antarctic Peninsula. Map was built using Ocean Data View (123). B) Pie charts

269 summarizing the number of PGFs considered present at each station based on cross mapping of

270 reads and the site of PGF assembly (phage origin). C) The heat map depicts the normalized

271 coverages based on cross-mapping of reads against the 78 PGFs and separation distances

272 between stations. White areas indicate PGFs that were not called present because they had less

273 than $75 \%$ of scaffold length covered in mapping (with least 1-fold coverage). D) Single- 
bioRxiv preprint doi: https://doi.org/10.1101/2021.11.09.467789; this version posted February 19, 2022. The copyright holder for this preprint (which was not certified by peer review) is the author/funder, who has granted bioRxiv a license to display the preprint in perpetuity. It is made available under aCC-BY-NC-ND 4.0 International license.

Rahlff et al.

Dispersal of Antarctic phage

274 nucleotide polymorphism (SNP) analysis of p12D/Antarcphage49_Dr_7823_circ based on

275 reads from Druzhnaja, Mirnii and the WAP. This PGF was absent from the metagenome of the

276 Progress station. Further SNP analysis data can be found in Table S6. E) Summary figure for

277 the major dispersal route and supporting evidence. The majority of PGF disperse between

278 Mirnii and Druzhnaja, and 13 PGFs additionally occurred at the WAP based on cross-mapping

$279(\mathrm{CM})$ and SNP analysis. Values refer to the number of tested features, which include number

280 of virus clusters (VC), number of shared viruses based on CM, virus-host matches based on k-

281 mer links (VHM), CRISPR-spacer matches (CSM). A VHM=1 indicates that one PGF has

282 infected host MAGs from two stations. No VC and only one CM were observed for Progress-

283 Druzhnaja and Progress-Mirnii. Therefore, this station was excluded from the summary. 
bioRxiv preprint doi: https://doi.org/10.1101/2021.11.09.467789; this version posted February 19, 2022. The copyright holder for this preprint (which was not certified by peer review) is the author/funder, who has granted bioRxiv a license to display the preprint in perpetuity. It is made available under aCC-BY-NC-ND 4.0 International license.

Rahlff et al.

Dispersal of Antarctic phage

284 Many PGFs formed VCs with no genomic relatedness to any known phages from the 285 ProkaryoticViralRefSeq v94 database. Others were, however, similar to known Ralstonia PGFs 286 (current family Inoviridae, order Tubulavirales) and hence clustered with those, such as p12D 287 with Ralstonia phage 1 NP-2014, or Antarcphage10_Mi_4716 with Ralstonia phage PE226 and 288 Ralstonia phage p12J (Figure 4, Table S1). Other Antarctic PGFs shared protein clusters with 289 Ralstonia phages from space equipment based on vConTACT2 or were related to phages of the 290 Caudovirales order from the RefSeq database (Figure 4).

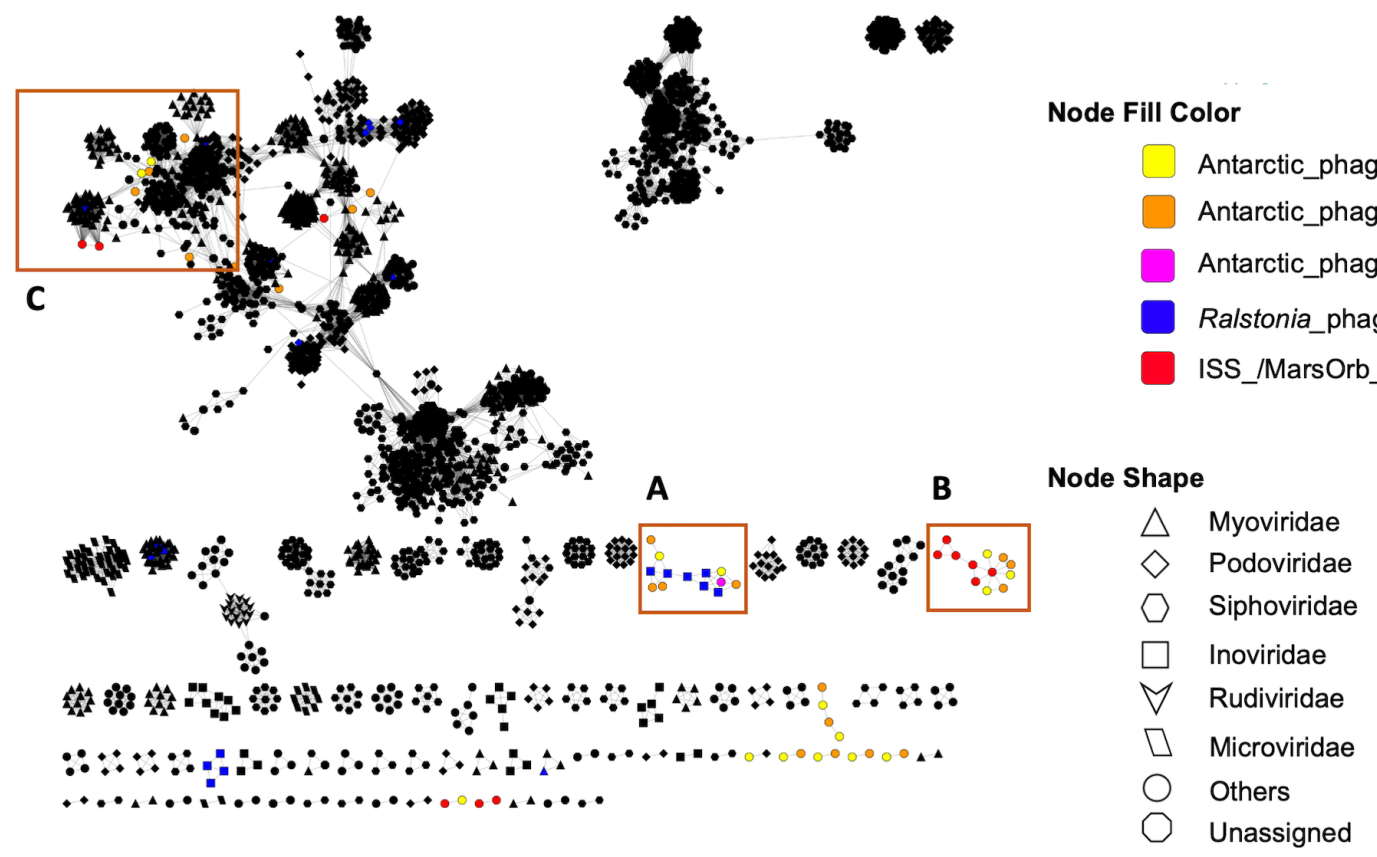

292 Figure 4: Phage network of Antarctic PGFs derived from Druzhnaja, Mirnii, Western Antarctic Peninsula (WAP) and space equipment (ISS/MarsOrb) clustered with viruses of the viral RefSeq database. Based on shared protein clusters, Antarctic PGFs from this study group with known Ralstonia phage of the family Inoviridae (A), with phages obtained from Ralstonia isolates from space equipment (B) or with known phages of the order Caudovirales 297 (C). Black nodes refer prokaryotic viruses other than Ralstonia and PGFs from this study. Interactions show relatedness of genomes on viral genus or higher taxonomic level. "Others" refer to other known viral families not listed in the legend. Visualization was done using Cytoscape 3.8.2. (109). For details about viral clusters, please see Table S1. 
bioRxiv preprint doi: https://doi.org/10.1101/2021.11.09.467789; this version posted February 19, 2022. The copyright holder for this preprint (which was not certified by peer review) is the author/funder, who has granted bioRxiv a license to display the preprint in perpetuity. It is made available under aCC-BY-NC-ND 4.0 International license.

Rahlff et al.

Dispersal of Antarctic phage

In summary, our results support the idea of dispersal of host-associated phages between widely

separated stations because a) cross-mapping revealed presence of Mirnii PGFs at Druzhnaja

and vice versa, presence of a temperate phage from snow in the WAP seawater dataset, and presence of the hosts Ralstonia and J. lividum in metagenomes of most stations; b) PGFs in widely separated locations carry identical SNPs or lack nucleotide variations; c) some PGFs from Mirnii and Druzhnaja belong to the same genus/VC; and d) Mirnii and Druzhnaja PGFs share host MAGs according to their k-mer frequency patterns. These observations were mainly true for PGFs affiliated to Ralstonia and J. lividum MAGs and less so for F. micromati PGFs,

310 which could indicate that certain bacterial species or their phages in Antarctic snow are more 311 prone to atmospheric dispersal than others. Finally, we found CRISPR spacers from two unidentified hosts (represented by two distinct CRISPR DR sequences) at the Mirnii station to

313 match PGFs from Druzhnaja, Mirnii and Progress. Mapping revealed little to no abundance of 314 Progress PGFs at other stations, and no F. micromati MAG was detected in Mirnii and WAP 315 samples. This could be related to the low biomass and/or or insufficient sequencing coverage. 316 However, spacers from Mirnii suggest an infection history with PGF from Progress, thus 317 reflecting (past) dispersal of host and/or phage.

\section{Ralstonia phages occur across diverse ecosystems and on space equipment}

By BLASTing all recovered PGFs against the IMG/VR viral database (41), we found that p12D

321 shared high identity (85.9 \%) with a $R$. pickettii prophage (IMG/VR v.2 scaffold ID

322 Ga0075447_10000781, genome ID: 3300006191) from a seawater metagenome of the WAP

323 (Figure 2), which was further validated by cross-mapping of WAP reads to p12D delivering $324100 \%$ scaffold coverage with $90 \%$ identical reads. The WAP is $4710 \mathrm{~km}$ away from the 
bioRxiv preprint doi: https://doi.org/10.1101/2021.11.09.467789; this version posted February 19, 2022. The copyright holder for this preprint (which was not certified by peer review) is the author/funder, who has granted bioRxiv a license to display the preprint in perpetuity. It is made available under aCC-BY-NC-ND 4.0 International license.

Rahlff et al.

Dispersal of Antarctic phage

325 Druzhnaja station (Figure 3C). The PGF Antarcphage79_WAP_18.3 was obtained by 326 BLASTing the p12D scaffold against the WAP assembly but was assembled containing 327 genomic regions extending the actual PGF. Based on vConTACT2, it was affiliated to the same 328 viral genus as p12D. Other PGFs recovered from the Antarctic snow metagenome showed hits 329 to phages deposited at IMG/VR. Hits were related to phages originating from freshwater, 330 wastewater, groundwater, or phages that were associated with plant root microbial 331 communities, which is in accordance with the fact that Ralstonia sp. is a frequent 332 phytopathogen (42). Many of the matching entries in IMG/VR were identified as phages of 333 Ralstonia due to matching with CRISPR spacers (mostly of $R$. solanacearum, Table S7).

Altogether, 14 PGFs were found on space equipment, hereafter referred to as ISSphage (7) and MarsOrbphage (7), for PGFs extracted from the R. pickettii strains CW2 and SSH4 draft genomes from the ISS cooling system and Mars Odyssey Orbiter, respectively. Seven of these PGFs were identified as lysogenic and according to protein annotations (Table S4 \& S5) rely on proteins of the integrase family for integration into the host chromosome. vConTACT2

340 revealed that some of the ISSphage4 formed a common genus cluster with four Antarctic PGFs, 341 MarsOrbphage5 shared protein clusters with ISSphage3, and MarsOrbphage7 formed a genus 342 cluster with several Burkholderia phages among other Caudovirales members (Figure 4, Table 343 S1).

\section{Discussion}

346 CRISPR-Cas systems equip bacteria and archaea with a powerful defense system against 347 invading mobile genetic elements including plasmids, phages and viruses. Only ca. 50\% of 348 bacteria rely on this adaptive immune system, and only $31 \%$ of genomes from public databases 349 belonging to plant-pathogenic Ralstonia solanacearum contain CRISPR-Cas arrays (43). Upon 
bioRxiv preprint doi: https://doi.org/10.1101/2021.11.09.467789; this version posted February 19, 2022. The copyright holder for this preprint (which was not certified by peer review) is the author/funder, who has granted bioRxiv a license to display the preprint in perpetuity. It is made available under aCC-BY-NC-ND 4.0 International license.

Rahlff et al.

Dispersal of Antarctic phage

350

351

352

353

354

355

356

357

358

359

360

361

362

363

364

365

366

367

368

369

370

371

372

373

374

exposure to a virulent phage under laboratory conditions, the CRISPR array of $R$. solanacearum strain CFBP2957 did not acquire new spacers from viral protospacers (43). O. S. Gonçalves et al. (28) reported that in the presence of CRISPR arrays, $27.9 \%$ of CRISPR spacers from Ralstonia genomes targeted prophage elements. In our study, two Ralstonia MAGs from a low temperature environment were devoid of CRISPR systems, implying that representatives of this genus have alternative strategies for defense against mobile genetic elements (43). However, analyses on more Ralstonia genomes are necessary to corroborate this statement.

Based on shared protein clusters, some Antarctic PGFs such as Antarcphage10_Mi_4716, Antarcphage48_Dr_1123, Antarcphage17_Mi_3026, and p12D clustered with known Ralstonia phages including Ralstonia phage p12J (NC_005131.2), Ralstonia phage PE226 (NC_015297.1) or Ralstonia phage 1 NP-2014 (NC_023586.1). These are filamentous phages of the Inoviridae, a family that has been recently called for reclassification to higher taxonomic ranks $(36,44)$. Inoviruses (order Tubulavirales) typically feature circular, single stranded DNA genomes of $\sim 5-15 \mathrm{~kb}$ length, lead to chronic infections, and are globally abundant (36). As our protocol should have only revealed double-stranded DNA, detection of ssDNA inoviruses sequences shows that these must be either replicating phages or genome-integrated prophages. Zot, which was detected on p12D, Antarcphage10_Mi_4716 and Antarcphage79_WAP_18.3 is a typical gene in filamentous Ralstonia phages $(45,46)$. This phage type confers little burden to its host or can even serve it, e.g., by increasing its hosts' virulence and evolutionary fitness, and because virions can leave the host in a non-destructible way $(35,36)$. Ralstonia phages detected in Arctic viromes were shown to transduce genomic information of cold-shock proteins to their hosts (47), a clear asset for microorganisms in polar environments. However, we did not find transduction of beneficial genes, which seems to be common in extreme environments (48). 
bioRxiv preprint doi: https://doi.org/10.1101/2021.11.09.467789; this version posted February 19, 2022. The copyright holder for this preprint (which was not certified by peer review) is the author/funder, who has granted bioRxiv a license to display the preprint in perpetuity. It is made available under aCC-BY-NC-ND 4.0 International license.

Rahlff et al.

Dispersal of Antarctic phage

375 Some Ralstonia phages occur as non-integrative, episomal forms, e.g., RS603, a hybrid of 376 RSM1/3 infecting the phytopathogen $R$. solanacearum (49), whose genome lacks a resolvase 377 domain (Figure 2A), but many mesophilic Ralstonia also occur as lysogens (50). Lysogeny, a 378 lifestyle during which the phage genome becomes integrated into the host chromosome, is a 379 widespread phenomenon in low temperature environments (51-53) and likely attributed to 380 prolonged starvation and low activity of host cells under harsh conditions, the latter being 381 previously reported for Ralstonia (15). Since p12D and its counterpart from the WAP have a 382 resolvase-domain containing protein likely functioning in integration/excision during 383 lysogenisation $(54,55)$, we conclude that they must be temperate phages of Ralstonia.

384 Many, i.e., 75 of the 78 Antarctic PGFs found in this study shared little protein clusters with 385 known phages from public databases. This is certainly related to the often high diversity of 386 viruses, limited accessibility to Antarctic environments as well as a stronger focus on 387 sequencing metaviromes and viral isolates of direct human interest (56). The missing 388 relatedness is known for ssDNA viruses originating from Antarctic cryoconite holes and was 389 attributed to the isolation and extreme environmental conditions at the Antarctic continent (57). 390 In total, 45 of the 78 PGFs could be assigned to a host, which in $71 \%$ of cases was Ralstonia 391 (summarized in Table S1, column "host prediction").

392 Aeolian transport of viruses over polar environments, especially attached to snowflakes, has 393 been barely investigated to date. Former investigations, mainly conducted at low latitudes, 394 demonstrated intercontinental transport of microbes by winds (58), and that highly identical 395 phages can be found in distantly related areas and in various ecosystems around the globe (59396 62). C. M. Bellas et al. (63) recently reported the presence of near-identical phage genomes 397 being spread by up to $4000 \mathrm{~km}$ in cryoconite holes of Svalbard, Greenland, and the Alps. Our 398 data show that despite the isolation of the Antarctic continent, and under no consideration of 399 anthropogenic dispersal (64), bacteria and phage distribution via snow over extensive distances 
bioRxiv preprint doi: https://doi.org/10.1101/2021.11.09.467789; this version posted February $19,2022$. The copyright holder for this preprint (which was not certified by peer review) is the author/funder, who has granted bioRxiv a license to display the preprint in perpetuity. It is made available under aCC-BY-NC-ND 4.0 International license.

Rahlff et al.

Dispersal of Antarctic phage

400

401

402

403

404

405

406

407

408

409

410

413

across Antarctica is possible. Man-made dispersal seems unlikely for our samples, due to the relatedness of Antarctic phages to phages from environmental sources according to database hits. We cannot be certain about the nature of the PGFs (prophage or lytic phage) by metagenomic predictions alone. While the Inoviridae fraction likely occurs as prophages or episomal forms, detection of PGFs assigned to lytic categories by VIBRANT and VirSorter (category 1-3) suggests that host-associated, lytic phages captured at the adsorption or infection stages were present as well. The degree of uncertainty about the category of a virus presumably results from many fragmented scaffolds with relatively low coverages, which were however sufficient to identify shared elements of viruses between stations. Conclusions about the presence/absence of hallmark genes should be drawn from more complete datasets based on greater sequencing depth of samples containing more biomass. We further commend experiments that involve cultivation attempts and sequencing of metaviromes (free phages) to reveal the extent of lysogenic or chronic compared to lytic infection styles in Antarctic snow.

Snow PGFs carried identical SNPs with those from the seawater metagenome from the WAP located $4710 \mathrm{~km}$ and $5338 \mathrm{~km}$ apart from Druzhnaja and Mirnii, respectively (Figure 3C), implying long distance transport. This is further supported by the detection of their hosts, Ralstonia and J. lividum, in the WAP. From seawater, a transmission route via sea spray aerosols to snow that is blown over ice surfaces (65) can be assumed. Aerosolization of bacteria from the sea surface is highly taxon-specific but seems to work well for R. pickettii (66) and also viruses (67). Alternatively, a transport via aerosols to clouds and precipitating snow is possible. In the latter scenario, bioaerosols including microbial cells would act as ice nucleation particles (68), transferring microbes to ice clouds where they might induce their own precipitation $(69,70)$. The abundance data support the isolation of Progress-derived PGFs and their potential host $F$. micromati and point towards a decreasing gradient of abundances from 
bioRxiv preprint doi: https://doi.org/10.1101/2021.11.09.467789; this version posted February $19,2022$. The copyright holder for this preprint (which was not certified by peer review) is the author/funder, who has granted bioRxiv a license to display the preprint in perpetuity. It is made available under aCC-BY-NC-ND 4.0 International license.

Rahlff et al.

Dispersal of Antarctic phage

Druzhnaja to Mirnii to the WAP for many PGFs (Table S1). Thus, general dispersal patterns of microbes across Antarctica seem governed by westward drift and are probably mediated by the prevailing Southern Hemisphere westerly winds (71). On short spatial-temporal scales, dispersal seems more complex and is probably shaped by multifactorial dependencies such as the different potential of a species to become airborne (66), meteorological conditions or the local geography. For instance, while Druzhnaja is located $\sim 50 \mathrm{~km}$ into the continent, the stations Mirnii and Progress are near the coast and more exposed to the sea in summer when ice breaks occur.

We assume that the transferability of the use of PGFs to study microbial dispersal in space analogues such as the Antarctic continent is likely applicable to other celestial bodies like Mars. Three celestial bodies in our solar system (Mars, Europa, and Enceladus) have environmental conditions that could favor microbial life (reviewed by M. G. Netea et al. (72)). Most microbial isolates (85-95\%) obtained from spacecraft and assembly facilities are associated with humans (73). Since Ralstonia spp. can be human and plant pathogens $(42,74)$ and are able to thrive under harsh and oligotrophic conditions (7), they might contribute to the transmission of viruses to extraterrestrial environments, particularly via manned missions.

We found evidence for viral signatures associated with two $R$. pickettii strain draft genomes previously obtained from space equipment of a spacecraft assembly clean room and from water systems of the ISS. This result in conjunction with the result that temperate Ralstonia phages (and other viruses) can undergo long-range dispersal in association with their hosts across the extraterrestrial analogue Antarctica suggest that contaminations of space equipment with particularly persistent microbes such as Ralstonia should receive more focus during microbiological monitoring in the framework of Planetary Protection. However, the field of astrovirology has so far generally found little attention (75). The contribution of lysogenic and episomal phage ('hidden hitchhikers') to overall viral loads on spacecraft and associated 
bioRxiv preprint doi: https://doi.org/10.1101/2021.11.09.467789; this version posted February $19,2022$. The copyright holder for this preprint (which was not certified by peer review) is the author/funder, who has granted bioRxiv a license to display the preprint in perpetuity. It is made available under aCC-BY-NC-ND 4.0 International license.

Rahlff et al.

Dispersal of Antarctic phage

450

451

452

453

454

455

456

457

458

459

460

461

462

463

464

465

equipment has been overlooked despite early work reporting on alterations in prophage induction during spaceflight (76-78), tobacco mosaic virus to survive space flight equivalent proton irradiation (79), the occurrence of phages and human-related circoviruses in clean rooms (80) and inoviruses on the ISS $(81,82)$.

Planetary Protection aims to prevent the spread of biological contaminants (forward contamination) to space shuttles and stations as well as extraterrestrial environments of the solar system. However, this policy largely ignores the potential of escaped biological contaminants to heavily disperse on foreign celestial bodies once being released, for instance after crash landings as happened for the Schiaparelli module of the ExoMars program in 2016 (83). Our results show that host-associated PGFs are not only suitable indicators for tracking longdistance dispersal in space analogues but also demonstrate that the release of contaminants that previously escaped Planetary Protection measures could spread far across extraterrestrial ecosystems and, in the worst-case scenario, confound future life detection missions.

\section{Material and Methods}

\section{Metagenomic and genomic data processing}

We analyzed publicly available metagenomic data sets, which correspond to Antarctic surface snow collected around three Russian stations (Druzhnaja, Mirnii, Progress) and are deposited at NCBI's Sequence Read Archive (SRA) as Bioproject PRJNA674475 (Table S8) and MGRAST under project accession mgp13052 including taxon abundance data. Snow sampling was conducted in December 2008 and 2009 as described previously (15); in brief, a sterile plastic scoop was used to sample $\sim 10 \mathrm{~kg}$ corresponding to a $2-3 \mathrm{~cm}$ layer of surface snow across several $1 \mathrm{~m}^{2}$ areas. Snow was melted over a period of 12 hours and concentrated using Pellicon tangential flow filters (Millipore, Burlington, MA, USA) to a final volume of $\sim 10 \mathrm{~mL}$. DNA 
bioRxiv preprint doi: https://doi.org/10.1101/2021.11.09.467789; this version posted February 19, 2022. The copyright holder for this preprint (which was not certified by peer review) is the author/funder, who has granted bioRxiv a license to display the preprint in perpetuity. It is made available under aCC-BY-NC-ND 4.0 International license.

Rahlff et al.

Dispersal of Antarctic phage

474

475

476

477

478

479

480

481

482

483

484

485

486

487

488

489

490

491

492

493

494

495

496

497

extraction for these metagenomes was carried out with the DNA Blood \& Tissue kit (Qiagen, Hilden, Germany), whose protocol causes removal of free viruses, and resulted in DNA amounts of $170-490$ ng. Sequencing libraries were prepared with MiSeq reagent kit v.2 (Illumina, USA), targeting mainly dsDNA viruses. Metagenomic data of a seawater sample from the WAP was also obtained from SRA (accession \#SRR5591034). Raw shotgun sequencing reads of the three snow metagenomes and the WAP dataset were quality-trimmed using BBDuk (https://github.com/BioInfoTools/BBMap/blob/master/sh/bbduk.sh) from the BBTools package (84) and Sickle (85) resulting in read counts between 1.31-2.65 Mio. for the three snow samples. Assembly of reads was done using MetaSPAdes version 3.13 (86), and scaffolds $<1$ kbps were removed. Draft genome sequences of $R$. pickettii strains SSH4 and CW2 isolated from space equipment were obtained from Genbank accession \#JFZG00000000 and \#JFZH00000000. Strains SSH4 and CW2 were isolated pre-flight from the surface of the Mars Odyssey Orbiter during assembly and from a water sample taken in-flight from the ISS cooling system, respectively (9).

\section{Reconstruction of microbial genomes from metagenomes and CRISPR prediction}

Binning of MAGs from the three stations Druzhnaja, Mirnii and Progress was performed using Emergent self-organizing

maps

(ESOMs,

ABAWACA (https://github.com/CK7/abawaca) and MaxBin 2.0 (88). Aggregation of bins was performed using DASTool (89) and curation of bins was done in uBin (90), also delivering contamination and completeness scores (91). Read coverage of recovered MAGs was obtained from read mapping using Bowtie2 (92) in sensitive mode to the individual bins, followed by mismatch filtering ( $2 \%$ mismatch allowance, depending on read length). To investigate the dispersal of MAGs, mismatch criteria were set to $0 \%$ mismatches $(100 \%$ similarity) and calcopo.rb 
bioRxiv preprint doi: https://doi.org/10.1101/2021.11.09.467789; this version posted February 19, 2022. The copyright holder for this preprint (which was not certified by peer review) is the author/funder, who has granted bioRxiv a license to display the preprint in perpetuity. It is made available under aCC-BY-NC-ND 4.0 International license.

Rahlff et al.

Dispersal of Antarctic phage

(https://github.com/ProbstLab/viromics/tree/master/calcopo) was used to calculate the coverage per nucleotide (breadth) and the percentage of positions in the genome covered by reads. Only genomes with a least $70 \%$ breadth were considered present in the respective metagenome.

CRISPR arrays, which represent the prokaryotic adaptive immunity, were searched in host MAGs using CRISPRcasFinder and considering evidence level 3 or 4 (29). CRISPR loci consist of repeats interspaced with short DNA sequences (spacers) obtained from invading mobile genetic elements such as phages and thus provide a record of past infections. Since CRISPR arrays might get lost during the binning processes, e.g., due to fragmentation in assembly of strain variants, absence of CRISPR arrays in CRISPRcasFinder was further investigated by reconstructing CRISPR systems from raw reads using Crass (93) and BLASTing the obtained direct repeat (DR) sequences, which are phylogenetically well-conserved (94), against the NCBI non-redundant database (release $1^{\text {st }}$ March 2021) using BLASTn --short algorithm (95) with subsequent filtering at $80 \%$ similarity and e-value threshold of $10 \mathrm{e}-05$. DR sequences were BLASTed against the MAGs and used to extract CRISPR spacers from reads using MetaCRAST with settings -d 3 -1 60 -c 0.99 -a 0.99 -r (96). Spacers were matched against PGFs as mentioned above for DRs. In most cases, BLASTing the DR sequences against the NR database did not reveal the host's identity. Nevertheless, spacers derived from unknown hosts were considered, as their matches show that targeted PGFs represent true mobile genetic elements, and matches can be used to infer infection patterns between stations.

\section{PGF detection, host allocation and viral clustering}

PGFs were identified from metagenome assemblies using a combination of bioinformatic tools, namely Virsorter v1 (33), VirFinder (97), CircMG (98), renamed to VRCA 
bioRxiv preprint doi: https://doi.org/10.1101/2021.11.09.467789; this version posted February 19, 2022. The copyright holder for this preprint (which was not certified by peer review) is the author/funder, who has granted bioRxiv a license to display the preprint in perpetuity. It is made available under aCC-BY-NC-ND 4.0 International license.

Rahlff et al.

Dispersal of Antarctic phage

522

523

524

525

526

527

528

529

530

531

532

533

534

535

536

537

538

539

540

541

542

543

544

545

(https://github.com/alexcritschristoph/VRCA), VOGdb (version VOG93) (99), and

Endmatcher (https://github.com/ProbstLab/viromics/tree/master/Endmatcher). The

classification of predicted PGFs as "putative viruses" and "viruses" was done as previously described in the Supplementary Figure 3 of (100). VIBRANT v.1.2.1 (30) with default settings was used to find additional PGFs. No length cut-off was set (101), since many known Ralstonia phages and inoviruses have genome sizes $<10 \mathrm{~kb}(36,50)$, and because of the low biomass of Antarctic snow samples little PGFs compared to other ecosystems were expected. VirSorter and VIBRANT aided in (pro)phage detection in draft genomes of $R$. pickettii from space equipment. CheckV (32) was used to determine the type of identified PGF and completeness, and viralComplete (31) was applied to predict closely related phages. PGFs associated with MAGs were identified by grepping the scaffold ID on the bins. Pairwise comparisons of Antarctic PGFs and clustering was done using nucleic acid- and amino acid-based VICTOR (39). The resulting intergenomic distances were used to infer a balanced minimum evolution tree with branch support via FASTME including Subtree Pruning and Regrafting (SPR) postprocessing (102) using the distance formula D0. Branch support was inferred from 100 pseudo-bootstrap replicates each. Trees were rooted at the midpoint (103) and visualized with FigTree v1.4.4 (104). Taxon boundaries at the species and genus level were estimated with the OPTSIL program (105), using the recommended clustering thresholds (39) and an F value (fraction of links required for cluster fusion) of 0.5 (106).

Clustering of PGFs from Antarctic snow and space equipment was further substantiated via vConTACT2 v.0.9.19 $(40,107)$ in combination with the ProkaryoticViralRefSeq database (v94, (108)) followed by visualization of viral clusters (VC) in Cytoscape v. 3.8 .2 (109). Virushost matches were determined using the tool VirHostMatcher (34) with $d_{2} *$ oligonucleotide frequency dissimilarity measures for a k-mer length of 6 . Viral genus clusters were determined 
bioRxiv preprint doi: https://doi.org/10.1101/2021.11.09.467789; this version posted February 19, 2022. The copyright holder for this preprint (which was not certified by peer review) is the author/funder, who has granted bioRxiv a license to display the preprint in perpetuity. It is made available under aCC-BY-NC-ND 4.0 International license.

Rahlff et al.

Dispersal of Antarctic phage

using VIRIDIC (110). Venn diagrams were calculated using the VIB-ugent webtool

\section{Mapping of reads to assembled PGFs and nucleotide polymorphism analysis}

550 We assume that presence of a PGF at two locations confirmed by read mapping represents 551 dispersal. To determine if an assembled PGF from a single sample occurred in other 552 metagenomes even if not being assembled, we performed read mapping following the 553 previously published guidelines (101): that reads should map to a PGF with at least 90\% identity 554 (Bowtie2 settings as in (111)), and more than 75\% of scaffold should have a coverage of at least 555 1x. To detect breadth of a PGF, we again used calcopo.rb (see above). Mean coverage of PGFs 556 was calculated using calc_coverage_v3 (https://github.com/ProbstLab/uBin-

557 helperscripts/blob/master/bin/04 01 calc_coverage_v3.rb) and normalized to sequencing depth. 558 Analysis of nucleotide polymorphisms was conducted for the 13 PGFs that underwent long 559 range dispersal, i.e., PGF being present in the WAP sample and at least one of the snow 560 metagenomes based on read mapping (Table S1). Variant analysis was performed in Geneious $561 \quad 11.1 .5$ (112) by applying default settings to the read-mappings generated as explained above.

\section{Gene prediction and annotations}

564 Open reading frames on PGFs were detected using Prodigal in meta mode (113). Functional 565 and taxonomic annotations of predicted proteins of PGFs were performed by DIAMOND 566 searches with a e-value of 10e-05 (114) against FunTaxDB (90) and by using DRAM-v (115). 567 For the full-length genome of the PGF p12D, annotations were improved using HHpred against 568 PDB, Pfam, UniProt-SwissProt-viral and NCBI_Conserved Domains ((116, 117), 
bioRxiv preprint doi: https://doi.org/10.1101/2021.11.09.467789; this version posted February 19, 2022. The copyright holder for this preprint (which was not certified by peer review) is the author/funder, who has granted bioRxiv a license to display the preprint in perpetuity. It is made available under aCC-BY-NC-ND 4.0 International license.

Rahlff et al.

Dispersal of Antarctic phage

569

570

571

572

573

574

575

576

577

578

579

580

581

582

583

584

https://toolkit.tuebingen.mpg.de/tools/hhpred) with a probability threshold of $70 \%$. Sequences of PGFs were BLASTed against IMG/VR 2.0 (118) with an e-value cut-off of 10e-05 to find related phages from other metagenomic datasets.

\section{Synteny of Ralstonia phage and phylogenetic comparison of the zot gene}

Synteny of known Ralstonia sp. phages from NCBI and all Antarctic PGFs that were identified herein and carried the zonular occludens toxin (zot, Pfam-ID: PF05707) was performed with tBLASTx comparisons using Easyfig v.2.2.5 (119) on .gbk files generated by Prokka (120). A phylogenetic tree for the MUSCLE-aligned (121) amino acid and nucleic acid sequences of zot was constructed using the FastTree (122) algorithm in Geneious 11.1.5 (112).

\section{Acknowledgements}

We acknowledge Ken Dreger for server administration and maintenance as well as Cristina Moraru for sharing insights on virus taxonomy.

\section{Author Contribution statement}

J.R. designed the study, wrote the manuscript, and carried out the analyses with input from T.L.V.B.; A.L. and K.S. generated the raw data and performed the sampling; A.J.P conceptualized the project, provided supervision, resources, and was involved in data interpretation; All authors edited drafts of the manuscript. 
bioRxiv preprint doi: https://doi.org/10.1101/2021.11.09.467789; this version posted February 19, 2022. The copyright holder for this

preprint (which was not certified by peer review) is the author/funder, who has granted bioRxiv a license to display the preprint in perpetuity. It is made available under aCC-BY-NC-ND 4.0 International license.

Rahlff et al.

Dispersal of Antarctic phage

591 For all authors, no competing financial interests exist.

592

\section{$593 \quad$ Funding statement}

594 We acknowledge funding from the German Aerospace Center (DLR) for the project DISPERS

595 (50WB1922). J.R. was partially supported by the German Science Foundation for the project 596 VIBOCAT (grant number DFG RA3432/1-1). A.J.P. and T.L.V.B. were supported by the

597 Ministerium für Kultur und Wissenschaft des Landes Nordrhein-Westfalen 598 ("Nachwuchsgruppe Dr. Alexander Probst").

599

600

\section{References:}

601 1. Pyne SJ. 2007. The extraterrestrial Earth: Antarctica as analogue for space

602 exploration. Space Policy 23:147-149.

603 2. Lugg D, Shepanek M. 1999. Space analogue studies in Antarctica. Acta Astronaut

604 44:693-9.

605 3. Onofri S, Selbmann L, Zucconi L, Pagano S. 2004. Antarctic microfungi as models for $606 \quad$ exobiology. Planet Space Sci 52:229-237.

607 4. Puskeppeleit M, Quintern LE, El Naggar S, Schott JU, Eschweiler U, Horneck G, 608 Bucker H. 1992. Long-term dosimetry of solar UV radiation in Antarctica with spores 609 of Bacillus subtilis. Appl Environ Microbiol 58:2355-9.

610 5. Nicholson WL, Munakata N, Horneck G, Melosh HJ, Setlow P. 2000. Resistance of 611 Bacillus endospores to extreme terrestrial and extraterrestrial environments. Microbiol $612 \quad$ Mol Biol Rev 64:548-72. 
bioRxiv preprint doi: https://doi.org/10.1101/2021.11.09.467789; this version posted February 19, 2022. The copyright holder for this

preprint (which was not certified by peer review) is the author/funder, who has granted bioRxiv a license to display the preprint in perpetuity. It is made available under aCC-BY-NC-ND 4.0 International license.

Rahlff et al.

Dispersal of Antarctic phage

613 6. Onofri S, Barreca D, Selbmann L, Isola D, Rabbow E, Horneck G, De Vera J, Hatton

614 J, Zucconi L. 2008. Resistance of Antarctic black fungi and cryptoendolithic

615 communities to simulated space and Martian conditions. Stud Mycol 61:99-109.

616 7. McAlister MB, Kulakov LA, O'Hanlon JF, Larkin MJ, Ogden KL. 2002. Survival and 617 nutritional requirements of three bacteria isolated from ultrapure water. J Ind $618 \quad$ Microbiol Biotechnol 29:75-82.

619 8. Mijnendonckx K, Provoost A, Ott CM, Venkateswaran K, Mahillon J, Leys N, Van Houdt R. 2013. Characterization of the survival ability of Cupriavidus metallidurans

9. Monsieurs P, Mijnendonckx K, Provoost A, Venkateswaran K, Ott CM, Leys N, Van Houdt R. 2014. Draft genome sequences of Ralstonia pickettii strains SSH4 and CW2, isolated from space equipment. Genome Announc 2.

10. Ott CM, Bruce RJ, Pierson DL. 2004. Microbial characterization of free floating condensate aboard the Mir space station. Microb Ecol 47:133-6.

627 11. Baker PW, Leff L. 2004. The effect of simulated microgravity on bacteria from the Mir space station. Microgravity Sci Technol 15:35-41.

12. Vaishampayan P, Osman S, Andersen G, Venkateswaran K. 2010. High-density 16S microarray and clone library-based microbial community composition of the Phoenix spacecraft assembly clean room. Astrobiology 10:499-508. characterization of the Mars Odyssey spacecraft and its encapsulation facility. Environ Microbiol 5:977-85. 
bioRxiv preprint doi: https://doi.org/10.1101/2021.11.09.467789; this version posted February 19, 2022. The copyright holder for this preprint (which was not certified by peer review) is the author/funder, who has granted bioRxiv a license to display the preprint in perpetuity. It is made available under aCC-BY-NC-ND 4.0 International license.

Rahlff et al.

Dispersal of Antarctic phage

638 15. Lopatina A, Krylenkov V, Severinov K. 2013. Activity and bacterial diversity of snow around Russian Antarctic stations. Res Microbiol 164:949-58.

640 16. Lopatina A, Medvedeva S, Shmakov S, Logacheva MD, Krylenkov V, Severinov K. 2016. Metagenomic analysis of bacterial communities of Antarctic surface snow. Front Microbiol 7:398. preference for different size classes of organic carbon: a study from Antarctic snow. Environ Monit Assess 184:5929-43.

18. Liu Y, Yao T, Jiao N, Kang S, Xu B, Zeng Y, Huang S, Liu X. 2009. Bacterial

19. Van Houdt R, De Boever P, Coninx I, Le Calvez C, Dicasillati R, Mahillon J, periodically confined Antarctic base Concordia. Microb Ecol 57:640-8.

20. Carpenter EJ, Lin S, Capone DG. 2000. Bacterial activity in South Pole snow. Appl

21. Michaud L, Lo Giudice A, Mysara M, Monsieurs P, Raffa C, Leys N, Amalfitano S, Van Houdt R. 2014. Snow surface microbiome on the High Antarctic Plateau (DOME C). PLoS One 9:e104505. MJ, Pearce DA. 2019. Spatial variability of Antarctic surface snow bacterial communities. Front Microbiol 10:461.

23. Pearce DA, Alekhina IA, Terauds A, Wilmotte A, Quesada A, Edwards A, 
bioRxiv preprint doi: https://doi.org/10.1101/2021.11.09.467789; this version posted February 19,2022 . The copyright holder for this

preprint (which was not certified by peer review) is the author/funder, who has granted bioRxiv a license to display the preprint in perpetuity. It is made available under aCC-BY-NC-ND 4.0 International license.

Rahlff et al.

Dispersal of Antarctic phage

663

664

665

666

667

668

669

670

671

672

673

674

675

676

677

678

679

680

681

682

683

684

685

686

687

688

Pellizari VH, Vincent WF. 2016. Aerobiology over Antarctica - A new initiative for atmospheric ecology. Front Microbiol 7:16.

24. Bottos EM, Woo AC, Zawar-Reza P, Pointing SB, Cary SC. 2014. Airborne bacterial populations above desert soils of the McMurdo Dry Valleys, Antarctica. Microb Ecol 67:120-8.

25. Behzad H, Gojobori T, Mineta K. 2015. Challenges and opportunities of airborne metagenomics. Genome Biol Evol 7:1216-26.

26. Bowers RM, Clum A, Tice H, Lim J, Singh K, Ciobanu D, Ngan CY, Cheng JF, Tringe SG, Woyke T. 2015. Impact of library preparation protocols and template quantity on the metagenomic reconstruction of a mock microbial community. BMC Genomics 16:856.

27. Hughes KA. 2003. Aerial dispersal and survival of sewage-derived faecal coliforms in Antarctica. Atmos Environ 37:3147-3155.

28. Gonçalves OS, de Oliveira Souza F, Bruckner FP, Santana MF, Alfenas-Zerbini P. 2021. Widespread distribution of prophages signaling the potential for adaptability and pathogenicity evolution of Ralstonia solanacearum species complex. Genomics 113:992-1000.

29. Couvin D, Bernheim A, Toffano-Nioche C, Touchon M, Michalik J, Neron B, Rocha EPC, Vergnaud G, Gautheret D, Pourcel C. 2018. CRISPRCasFinder, an update of CRISRFinder, includes a portable version, enhanced performance and integrates search for Cas proteins. Nucleic Acids Res 46:W246-W251.

30. Kieft K, Zhou Z, Anantharaman K. 2020. VIBRANT: automated recovery, annotation and curation of microbial viruses, and evaluation of viral community function from genomic sequences. Microbiome 8:90.

31. Antipov D, Raiko M, Lapidus A, Pevzner PA. 2020. Metaviral SPAdes: assembly of viruses from metagenomic data. Bioinformatics 36:4126-4129. 
bioRxiv preprint doi: https://doi.org/10.1101/2021.11.09.467789; this version posted February 19,2022 . The copyright holder for this preprint (which was not certified by peer review) is the author/funder, who has granted bioRxiv a license to display the preprint in perpetuity. It is made available under aCC-BY-NC-ND 4.0 International license.

Rahlff et al.

Dispersal of Antarctic phage

689

690

691

692

693

694

695

696

697

698

699

700

701

702

703

704

705

706

707

708

709

710

711

712

32. Nayfach S, Camargo AP, Schulz F, Eloe-Fadrosh E, Roux S, Kyrpides NC. 2020. CheckV assesses the quality and completeness of metagenome-assembled viral genomes. Nat Biotechnol doi:10.1038/s41587-020-00774-7.

33. Roux S, Enault F, Hurwitz BL, Sullivan MB. 2015. VirSorter: mining viral signal from microbial genomic data. PeerJ 3:e985.

34. Ahlgren NA, Ren J, Lu YY, Fuhrman JA, Sun F. 2017. Alignment-free $\$ d \_2^{\wedge * \$}$ oligonucleotide frequency dissimilarity measure improves prediction of hosts from metagenomically-derived viral sequences. Nucleic Acids Res 45:39-53.

35. Hay ID, Lithgow T. 2019. Filamentous phages: masters of a microbial sharing economy. EMBO Rep 20.

36. Roux S, Krupovic M, Daly RA, Borges AL, Nayfach S, Schulz F, Sharrar A, Matheus Carnevali PB, Cheng JF, Ivanova NN, Bondy-Denomy J, Wrighton KC, Woyke T, Visel A, Kyrpides NC, Eloe-Fadrosh EA. 2019. Cryptic inoviruses revealed as pervasive in bacteria and archaea across Earth's biomes. Nat Microbiol 4:1895-1906.

37. Filée J, Forterre P, Laurent J. 2003. The role played by viruses in the evolution of their hosts: a view based on informational protein phylogenies. Res Microbiol 154:237-243.

38. Moreira D. 2000. Multiple independent horizontal transfers of informational genes from bacteria to plasmids and phages: implications for the origin of bacterial replication machinery. Mol Microbiol 35:1-5.

39. Meier-Kolthoff JP, Göker M. 2017. VICTOR: genome-based phylogeny and classification of prokaryotic viruses. Bioinformatics 33:3396-3404.

40. Bolduc B, Jang HB, Doulcier G, You ZQ, Roux S, Sullivan MB. 2017. vConTACT: an iVirus tool to classify double-stranded DNA viruses that infect Archaea and Bacteria. PeerJ 5:e3243. 
bioRxiv preprint doi: https://doi.org/10.1101/2021.11.09.467789; this version posted February 19,2022 . The copyright holder for this

preprint (which was not certified by peer review) is the author/funder, who has granted bioRxiv a license to display the preprint in perpetuity. It is made available under aCC-BY-NC-ND 4.0 International license.

Rahlff et al.

Dispersal of Antarctic phage

41. Prospero JM, Blades E, Mathison G, Naidu R. 2005. Interhemispheric transport of viable fungi and bacteria from Africa to the Caribbean with soil dust. Aerobiologia 21:1-19.

42. Askora A, Kawasaki T, Usami S, Fujie M, Yamada T. 2009. Host recognition and integration of filamentous phage phiRSM in the phytopathogen, Ralstonia solanacearum. Virology 384:69-76.

43. da Silva Xavier A, de Almeida JCF, de Melo AG, Rousseau GM, Tremblay DM, de Rezende RR, Moineau S, Alfenas-Zerbini P. 2019. Characterization of CRISPR-Cas systems in the Ralstonia solanacearum species complex. Mol Plant Pathol 20:223239.

44. Koonin EV, Dolja VV, Krupovic M, Varsani A, Wolf YI, Yutin N, Zerbini FM, Kuhn JH. 2020. Global organization and proposed megataxonomy of the virus world. Microbiol Mol Biol Rev 84.

45. Murugaiyan S, Bae JY, Wu J, Lee SD, Um HY, Choi HK, Chung E, Lee JH, Lee SW. 2011. Characterization of filamentous bacteriophage PE226 infecting Ralstonia solanacearum strains. J Appl Microbiol 110:296-303.

46. Mai-Prochnow A, Hui JG, Kjelleberg S, Rakonjac J, McDougald D, Rice SA. 2015. 'Big things in small packages: the genetics of filamentous phage and effects on fitness of their host'. FEMS Microbiol Rev 39:465-87.

47. Sanguino L, Franqueville L, Vogel TM, Larose C. 2015. Linking environmental prokaryotic viruses and their host through CRISPRs. FEMS Microbiol Ecol 91.

48. Hwang Y, Rahlff J, Schulze-Makuch D, Schloter M, Probst AJ. 2021. Diverse Viruses Carrying Genes for Microbial Extremotolerance in the Atacama Desert Hyperarid Soil. mSystems 6:e0385-21. 
bioRxiv preprint doi: https://doi.org/10.1101/2021.11.09.467789; this version posted February 19, 2022. The copyright holder for this preprint (which was not certified by peer review) is the author/funder, who has granted bioRxiv a license to display the preprint in perpetuity. It is made available under aCC-BY-NC-ND 4.0 International license.

Rahlff et al.

Dispersal of Antarctic phage

49. Van TTB, Yoshida S, Miki K, Kondo A, Kamei K. 2014. Genomic characterization of $\phi \mathrm{RS603}$, a filamentous bacteriophage that is infectious to the phytopathogen Ralstonia solanacearum. Microbiology and immunology 58:697-700.

50. Askora A, Yamada T. 2015. Two different evolutionary lines of filamentous phages in Ralstonia solanacearum: their effects on bacterial virulence. Front Genet 6:217.

51. Filippova SN, Surgucheva NA, Sorokin VV, Akimov VN, Karnysheva EA, Brushkov AV, Andersen D, Gal'chenko VF. 2016. Bacteriophages in Arctic and Antarctic lowtemperature systems. Microbiology 85:359-366.

52. Dziewit L, Radlinska M. 2016. Two inducible prophages of an Antarctic Pseudomonas sp. ANT_H14 use the same capsid for packaging their genomes Characterization of a novel phage helper-satellite system. PLoS One 11:e0158889.

53. Filippova SN, Surgucheva NA, Kulikov EE, Sorokin VV, Akimov VN, Bej AK, McKay C, Andersen D, Galchenko VF. 2013. Detection of phage infection in the bacterial population of Lake Untersee (Antarctica). Microbiology 82:383-386.

54. Askora A, Kawasaki T, Fujie M, Yamada T. 2011. Resolvase-like serine recombinase mediates integration/excision in the bacteriophage phiRSM. J Biosci Bioeng 111:10916.

55. Ahmad AA, Stulberg MJ, Mershon JP, Mollov DS, Huang Q. 2017. Molecular and biological characterization of varphiRs551, a filamentous bacteriophage isolated from a race 3 biovar 2 strain of Ralstonia solanacearum. PLoS One 12:e0185034.

56. Rodrigues RAL, Andrade A, Boratto PVM, Trindade GS, Kroon EG, Abrahao JS. 2017. An anthropocentric view of the virosphere-host relationship. Front Microbiol $8: 1673$.

57. Sommers P, Fontenele RS, Kringen T, Kraberger S, Porazinska DL, Darcy JL, Schmidt SK, Varsani A. 2019. Single-stranded DNA viruses in Antarctic cryoconite holes. Viruses 11. 
bioRxiv preprint doi: https://doi.org/10.1101/2021.11.09.467789; this version posted February 19,2022 . The copyright holder for this

preprint (which was not certified by peer review) is the author/funder, who has granted bioRxiv a license to display the preprint in perpetuity. It is made available under aCC-BY-NC-ND 4.0 International license.

Rahlff et al.

Dispersal of Antarctic phage

58. Smith DJ, Timonen HJ, Jaffe DA, Griffin DW, Birmele MN, Perry KD, Ward PD, Roberts MS. 2013. Intercontinental dispersal of bacteria and archaea by transpacific winds. Appl Environ Microbiol 79:1134-9.

59. Short CM, Suttle CA. 2005. Nearly identical bacteriophage structural gene sequences are widely distributed in both marine and freshwater environments. Appl Environ Microb 71:480-486.

60. Breitbart M, Rohwer F. 2005. Here a virus, there a virus, everywhere the same virus? Trends Microbiol 13:278-84.

61. Breitbart M, Miyake JH, Rohwer F. 2004. Global distribution of nearly identical phage-encoded DNA sequences. FEMS Microbiol Lett 236:249-56.

62. Li Y, Endo H, Gotoh Y, Watai H, Ogawa N, Blanc-Mathieu R, Yoshida T, Ogata H. 2019. The Earth is small for "Leviathans": Long distance dispersal of giant viruses across aquatic environments. Microbes Environ 34:334-339.

63. Bellas CM, Schroeder DC, Edwards A, Barker G, Anesio AM. 2020. Flexible genes establish widespread bacteriophage pan-genomes in cryoconite hole ecosystems. Nat Commun 11:4403.

64. Hughes KA, Convey P, Pertierra LR, Vega GC, Aragon P, Olalla-Tarraga MA. 2019. Human-mediated dispersal of terrestrial species between Antarctic biogeographic regions: A preliminary risk assessment. J Environ Manage 232:73-89.

65. Benninghoff W, Benninghoff A. 1985. Wind transport of electrostatically charged particles and minute organisms in Antarctica, p 592-596, Antarctic nutrient cycles and food webs. Springer.

66. Michaud JM, Thompson LR, Kaul D, Espinoza JL, Richter RA, Xu ZZ, Lee C, Pham KM, Beall CM, Malfatti F, Azam F, Knight R, Burkart MD, Dupont CL, Prather KA. 2018. Taxon-specific aerosolization of bacteria and viruses in an experimental oceanatmosphere mesocosm. Nat Commun 9:2017. 
bioRxiv preprint doi: https://doi.org/10.1101/2021.11.09.467789; this version posted February 19,2022 . The copyright holder for this

preprint (which was not certified by peer review) is the author/funder, who has granted bioRxiv a license to display the preprint in perpetuity. It is made available under aCC-BY-NC-ND 4.0 International license.

Rahlff et al.

Dispersal of Antarctic phage

67. Aller JY, Kuznetsova MR, Jahns CJ, Kemp PF. 2005. The sea surface microlayer as a source of viral and bacterial enrichment in marine aerosols. J Aerosol Sci 36:801-812.

68. Wilbourn EK, Thornton DCO, Ott C, Graff J, Quinn PK, Bates TS, Betha R, Russell LM, Behrenfeld MJ, Brooks SD. 2020. Ice nucleation by marine aerosols over the North Atlantic Ocean in late spring. J Geophys Res Atmos 125:e2019JD030913.

69. Amato P. 2012. Clouds provide atmospheric oases for microbes. Microbe 7:119-123.

70. Christner BC, Morris CE, Foreman CM, Cai R, Sands DC. 2008. Ubiquity of biological ice nucleators in snowfall. Science 319:1214.

71. Strother SL, Salzmann U, Roberts SJ, Hodgson DA, Woodward J, Van Nieuwenhuyze W, Verleyen E, Vyverman W, Moreton SG. 2015. Changes in Holocene climate and the intensity of Southern Hemisphere Westerly Winds based on a high-resolution palynological record from sub-Antarctic South Georgia. Holocene 25:263-279.

72. Netea MG, Dominguez-Andres J, Eleveld M, Op den Camp HJM, van der Meer JWM, Gow NAR, de Jonge MI. 2020. Immune recognition of putative alien microbial structures: Host-pathogen interactions in the age of space travel. PLoS Pathog 16:e1008153.

73. Nicholson WL, Schuerger AC, Race MS. 2009. Migrating microbes and planetary protection. Trends Microbiol 17:389-92.

74. Coenye T, Vandamme P, LiPuma JJ. 2002. Infection by Ralstonia species in cystic fibrosis patients: identification of $R$. pickettii and $R$. mannitolilytica by polymerase chain reaction. Emerg Infect Dis 8:692-6.

75. Berliner AJ, Mochizuki T, Stedman KM. 2018. Astrovirology: Viruses at large in the universe. Astrobiology 18:207-223.

76. Mattoni RHT, Keller Jr EC. 1972. Induction of lysogenic bacteria in the space. The Experiments of Biosatellite II 204:309. 
bioRxiv preprint doi: https://doi.org/10.1101/2021.11.09.467789; this version posted February $19,2022$. The copyright holder for this

preprint (which was not certified by peer review) is the author/funder, who has granted bioRxiv a license to display the preprint in perpetuity. It is made available under aCC-BY-NC-ND 4.0 International license.

Rahlff et al.

Dispersal of Antarctic phage

814 77. Mattoni RHT. 1968. Influence of spaceflight and radiation on induction of prophage P-22 in Salmonella typhimurium. Jpn J Genet 43:465-465.

78. Mattoni RHT. 1968. Space-flight effects and gamma radiation interaction on growth and induction of lysogenic bacteria, a preliminary report. BioScience 18:602-608.

79. Koike J. 1991. Fundamental questions concerning the contamination of other planets with terrestrial microorganisms carried by space-probes. The Journal of Space

80. Weinmaier T, Probst AJ, La Duc MT, Ciobanu D, Cheng JF, Ivanova N, Rattei T, Vaishampayan P. 2015. A viability-linked metagenomic analysis of cleanroom environments: eukarya, prokaryotes, and viruses. Microbiome 3:62.

81. Mora M, Wink L, Kogler I, Mahnert A, Rettberg P, Schwendner P, Demets R, Cockell Moeller R. 2022. Spaceflight virology: What do we know about viral threats in the Debei S. 2018. ExoMars 2016 Schiaparelli module trajectory and atmospheric profiles reconstruction. Space Science Reviews 214:1-31.

84. Bushnell B. 2014. BBTools software package. URL http://sourceforge net/projects/bbmap 578:579. tool for FastQ files (Version 1.33)[Software]. 
bioRxiv preprint doi: https://doi.org/10.1101/2021.11.09.467789; this version posted February 19,2022 . The copyright holder for this

preprint (which was not certified by peer review) is the author/funder, who has granted bioRxiv a license to display the preprint in perpetuity. It is made available under aCC-BY-NC-ND 4.0 International license.

Rahlff et al.

Dispersal of Antarctic phage

840 87. Dick GJ, Andersson AF, Baker BJ, Simmons SL, Thomas BC, Yelton AP, Banfield JF. 2009. Community-wide analysis of microbial genome sequence signatures.

843 88. Wu YW, Simmons BA, Singer SW. 2016. MaxBin 2.0: an automated binning algorithm to recover genomes from multiple metagenomic datasets. Bioinformatics $32: 605-7$.

89. Sieber CMK, Probst AJ, Sharrar A, Thomas BC, Hess M, Tringe SG, Banfield JF. 2018. Recovery of genomes from metagenomes via a dereplication, aggregation and

90. Bornemann TLV, Esser SP, Stach L, Burg T, Probst AJ. 2020. uBin - a manual refining tool for metagenomic bins designed for educational purposes. bioRxiv doi:10.1101/2020.07.15.204776

91. Probst AJ, Castelle CJ, Singh A, Brown CT, Anantharaman K, Sharon I, Hug LA, Burstein D, Emerson JB, Thomas BC, Banfield JF. 2017. Genomic resolution of a cold subsurface aquifer community provides metabolic insights for novel microbes

856 92. Langmead B, Salzberg SL. 2012. Fast gapped-read alignment with Bowtie 2. Nat Methods 9:357-9.

93. Skennerton CT, Imelfort M, Tyson GW. 2013. Crass: identification and reconstruction of CRISPR from unassembled metagenomic data. Nucleic Acids Res 41:e105.

860 94. Mojica FJ, Diez-Villasenor C, Soria E, Juez G. 2000. Biological significance of a family of regularly spaced repeats in the genomes of Archaea, Bacteria and

863 95. Altschul SF. 2001. BLAST algorithm. e LS.

864 96. Moller AG, Liang C. 2017. MetaCRAST: reference-guided extraction of CRISPR spacers from unassembled metagenomes. PeerJ 5:e3788. 
bioRxiv preprint doi: https://doi.org/10.1101/2021.11.09.467789; this version posted February $19,2022$. The copyright holder for this

preprint (which was not certified by peer review) is the author/funder, who has granted bioRxiv a license to display the preprint in perpetuity. It is made available under aCC-BY-NC-ND 4.0 International license.

Rahlff et al.

Dispersal of Antarctic phage

866

867

868

869

870

871

872

873

874

875

876

877

878

879

880

881

882

883

884

885

886

887

888

97. Ren J, Ahlgren NA, Lu YY, Fuhrman JA, Sun F. 2017. VirFinder: a novel k-mer based tool for identifying viral sequences from assembled metagenomic data. Microbiome 5:69.

98. Crits-Christoph A, Gelsinger DR, Ma B, Wierzchos J, Ravel J, Davila A, Casero MC, DiRuggiero J. 2016. Functional interactions of archaea, bacteria and viruses in a hypersaline endolithic community. Environ Microbiol 18:2064-77.

99. Marz M, Beerenwinkel N, Drosten C, Fricke M, Frishman D, Hofacker IL, Hoffmann D, Middendorf M, Rattei T, Stadler PF, Topfer A. 2014. Challenges in RNA virus bioinformatics. Bioinformatics 30:1793-9.

100. Rahlff J, Turzynski V, Esser SP, Monsees I, Bornemann TLV, Figueroa-Gonzalez PA, Schulz F, Woyke T, Klingl A, Moraru C, Probst AJ. 2021. Lytic archaeal viruses infect abundant primary producers in Earth's crust. Nat Commun 12:4642.

101. Roux S, Emerson JB, Eloe-Fadrosh EA, Sullivan MB. 2017. Benchmarking viromics: an in silico evaluation of metagenome-enabled estimates of viral community composition and diversity. PeerJ 5:e3817.

102. Lefort V, Desper R, Gascuel O. 2015. FastME 2.0: A comprehensive, accurate, and fast distance-based phylogeny inference program. Mol Biol Evol 32:2798-800.

103. Farris JS. 1972. Estimating phylogenetic trees from distance matrices. The American Naturalist 106:645-668.

104. Rambaut A. 2006. FigTree, a graphical viewer of phylogenetic trees and as a program for producing publication-ready figures.

105. Göker M, Garcia-Blazquez G, Voglmayr H, Telleria MT, Martin MP. 2009. Molecular taxonomy of phytopathogenic fungi: a case study in Peronospora. PLoS One 4:e6319.

106. Meier-Kolthoff JP, Hahnke RL, Petersen J, Scheuner C, Michael V, Fiebig A, Rohde C, Rohde M, Fartmann B, Goodwin LA, Chertkov O, Reddy T, Pati A, Ivanova NN, Markowitz V, Kyrpides NC, Woyke T, Göker M, Klenk HP. 2014. Complete genome 
bioRxiv preprint doi: https://doi.org/10.1101/2021.11.09.467789; this version posted February 19,2022 . The copyright holder for this preprint (which was not certified by peer review) is the author/funder, who has granted bioRxiv a license to display the preprint in perpetuity. It is made available under aCC-BY-NC-ND 4.0 International license.

Rahlff et al.

Dispersal of Antarctic phage

892

893

894

895

896

897

898

899

900

901

902

903

904

905

906

907

908

909

910

911

912

913

914

915

916 sequence of DSM 30083(T), the type strain (U5/41(T)) of Escherichia coli, and a proposal for delineating subspecies in microbial taxonomy. Stand Genomic Sci 9:2.

107. Bin Jang H, Bolduc B, Zablocki O, Kuhn JH, Roux S, Adriaenssens EM, Brister JR, Kropinski AM, Krupovic M, Lavigne R, Turner D, Sullivan MB. 2019. Taxonomic assignment of uncultivated prokaryotic virus genomes is enabled by gene-sharing networks. Nat Biotechnol 37:632-639.

108. Brister JR, Ako-Adjei D, Bao Y, Blinkova O. 2015. NCBI viral genomes resource. Nucleic Acids Res 43:D571-7.

109. Shannon P, Markiel A, Ozier O, Baliga NS, Wang JT, Ramage D, Amin N, Schwikowski B, Ideker T. 2003. Cytoscape: a software environment for integrated models of biomolecular interaction networks. Genome Res 13:2498-504.

110. Moraru C, Varsani A, Kropinski AM. 2020. VIRIDIC-A novel tool to calculate the intergenomic similarities of prokaryote-infecting viruses. Viruses 12.

111. Nilsson E, Bayfield OW, Lundin D, Antson AA, Holmfeldt K. 2020. Diversity and host interactions among virulent and temperate Baltic Sea Flavobacterium phages. Viruses 12:158.

112. Kearse M, Moir R, Wilson A, Stones-Havas S, Cheung M, Sturrock S, Buxton S, Cooper A, Markowitz S, Duran C, Thierer T, Ashton B, Meintjes P, Drummond A. 2012. Geneious Basic: an integrated and extendable desktop software platform for the organization and analysis of sequence data. Bioinformatics 28:1647-9.

113. Hyatt D, Chen GL, Locascio PF, Land ML, Larimer FW, Hauser LJ. 2010. Prodigal: prokaryotic gene recognition and translation initiation site identification. BMC Bioinformatics 11:119.

114. Buchfink B, Xie C, Huson DH. 2015. Fast and sensitive protein alignment using DIAMOND. Nature Methods 12:59-60. 
bioRxiv preprint doi: https://doi.org/10.1101/2021.11.09.467789; this version posted February 19,2022 . The copyright holder for this preprint (which was not certified by peer review) is the author/funder, who has granted bioRxiv a license to display the preprint in perpetuity. It is made available under aCC-BY-NC-ND 4.0 International license.

Rahlff et al.

Dispersal of Antarctic phage

115. Shaffer M, Borton MA, McGivern BB, Zayed AA, La Rosa SL, Solden LM, Liu P, Narrowe AB, Rodriguez-Ramos J, Bolduc B, Gazitua MC, Daly RA, Smith GJ, Vik DR, Pope PB, Sullivan MB, Roux S, Wrighton KC. 2020. DRAM for distilling microbial metabolism to automate the curation of microbiome function. Nucleic Acids Res 48:8883-8900.

116. Zimmermann L, Stephens A, Nam SZ, Rau D, Kubler J, Lozajic M, Gabler F, Soding J, Lupas AN, Alva V. 2018. A completely reimplemented MPI bioinformatics toolkit with a new HHpred server at its core. J Mol Biol 430:2237-2243.

117. Söding J, Biegert A, Lupas AN. 2005. The HHpred interactive server for protein homology detection and structure prediction. Nucleic Acids Res 33:W244-8.

118. Paez-Espino D, Roux S, Chen IA, Palaniappan K, Ratner A, Chu K, Huntemann M, Reddy TBK, Pons JC, Llabres M, Eloe-Fadrosh EA, Ivanova NN, Kyrpides NC. 2019. IMG/VR v.2.0: an integrated data management and analysis system for cultivated and environmental viral genomes. Nucleic Acids Res 47:D678-D686.

119. Sullivan MJ, Petty NK, Beatson SA. 2011. Easyfig: a genome comparison visualizer. Bioinformatics 27:1009-10.

120. Seemann T. 2014. Prokka: rapid prokaryotic genome annotation. Bioinformatics 30:2068-9.

121. Edgar RC. 2004. MUSCLE: a multiple sequence alignment method with reduced time and space complexity. BMC Bioinformatics 5:113.

122. Price MN, Dehal PS, Arkin AP. 2010. FastTree 2--approximately maximumlikelihood trees for large alignments. PLoS One 5:e9490.

123. Schlitzer R. 2015. Ocean Data View. https://odv.awi.de/. 